University of Nebraska - Lincoln

DigitalCommons@University of Nebraska - Lincoln

Faculty Publications: Department of Teaching, Department of Teaching, Learning and Teacher Learning and Teacher Education

Education

9-29-2005

\title{
Preparing Teachers to Create a Mainstream Science Classroom Conducive to the Needs of English-Language Learners: A Feminist Action Research Project
}

\author{
Gayle A. Buck \\ University of Nebraska-Lincoln, gabuck@indiana.edu \\ Colette Mast \\ University of Nebraska-Lincoln \\ Nancy Ehlers \\ University of Nebraska-Lincoln \\ Elizabeth Franklin \\ University of Northern Colorado
}

Follow this and additional works at: https://digitalcommons.unl.edu/teachlearnfacpub

Part of the Teacher Education and Professional Development Commons

Buck, Gayle A.; Mast, Colette; Ehlers, Nancy; and Franklin, Elizabeth, "Preparing Teachers to Create a Mainstream Science Classroom Conducive to the Needs of English-Language Learners: A Feminist Action Research Project" (2005). Faculty Publications: Department of Teaching, Learning and Teacher Education. 7.

https://digitalcommons.unl.edu/teachlearnfacpub/7

This Article is brought to you for free and open access by the Department of Teaching, Learning and Teacher Education at DigitalCommons@University of Nebraska - Lincoln. It has been accepted for inclusion in Faculty Publications: Department of Teaching, Learning and Teacher Education by an authorized administrator of DigitalCommons@University of Nebraska - Lincoln. 


\title{
Preparing Teachers to Create a Mainstream Science Classroom Conducive to the Needs of English-Language Learners: A Feminist Action Research Project
}

\author{
Gayle Buck, ${ }^{1}$ Colette Mast, ${ }^{1}$ Nancy Ehlers, ${ }^{1}$ Elizabeth Franklin ${ }^{2}$ \\ ${ }^{1}$ Department of Teaching, Learning $\Xi 3$ Teacher Education, University of Nebraska-Lincoln, \\ 118 Henzlik Hall, Lincoln, Nebraska 68588-0355 \\ ${ }^{2}$ Center for Language Arts Education, University of Northern Colorado, Greeley, Colorado \\ Received 1 June 2004; Accepted 20 December 2004
}

\begin{abstract}
A feminist action research team, which consisted of a science educator, an English-language learner (ELL) educator, a first-year science teacher, and a graduate assistant, set a goal to work together to explore the process a beginning teacher goes through to establish a classroom conducive to the needs of middle-level ELL learners. The guiding questions of the study were answered by gathering a wealth of data over the course of 5 months and taken from the classroom, planning sessions, and researchers and students. These data were collected by observations, semistructured interviews, and written document reviews. The progressive analysis ultimately revealed that: (a) successful strategies a beginning teacher must utilize for teaching middle-level ELL children in a mainstream classroom involve complex structural considerations that are not part of the teacher's preparation; (b) learning increases for all children, but there are differences in learning achievement between ELL and non-ELL children; and (c) student and peer feedback proved to be an effective means of enhancing the growth of a beginning teacher seeking to increase her skills in teaching ELL learners. The experiences and findings from this project have implications for teacher preparation programs committed to preparing educators to teach science to all children.
\end{abstract}

(C) 2005 Wiley Periodicals, Inc. J Res Sci Teach 42: 1013-1031, 2005

Science education reform initiatives promote a vision of science for all students. According to the National Science Standards, “... skilled teachers recognize the diversity of their classes and organize the classroom so that all students have the opportunity to participate fully" (National Research Council, 1996, p. 36). However, research indicates that many science teachers have not developed teaching strategies to support the learning of an increasing percentage of the student population-English-language learners (ELLs).

Contract grant sponsor: U.S. Department of Education Bilingual Education.

Correspondence to: G. Buck; E-mail: gbuck@unlnotes.unl.edu

DOI 10.1002/tea.20085

Published online 29 September 2005 in Wiley InterScience (www.interscience.wiley.com).

(C) 2005 Wiley Periodicals, Inc. Used by permission. 
The number of ELLs in the public schools has been increasing since 1986. In 1997, 22 states reported the percentage of ELLs increased by more than 10\%, and 9 states reported increases of $25 \%$ or more (Macias, 1998). Overall, the number of ELL children in the USA has increased by more than 68\% in the past 10 years (Teachers of English to Speakers of Other Languages, 1997). As a group, these children represent the fastest growing segment of the population of schools (Fradd \& Lee, 1999). This student population is impacting the mainstream classroom and, consequently, the knowledge, skills, and experiences that science teachers require to make the mainstream classroom more conducive to the needs of all children.

Increasingly, responsibility for teaching ELLs is up to mainstream teachers (Comell, 1995; Sleeter, 2001). According to Sleeter (2001), 39\% of all teachers now have ELLs in their classrooms. Often these mainstream teachers lack adequate preparation to work with these children (Fradd \& Lee, 1999; Gersten, 1999; Goldenberg, 1996; McKeon, 1994; Sleeter, 2001; Valdes, 1998). In fact, teacher education programs often reinforce their existing biases. For example, practicum experiences in classrooms in which the learning needs of ELL children are not being met may reinforce an existing notion that achievement difference results from student deficits. Teacher education efforts to extend the knowledge, skills, and experiences necessary for these contemporary science teachers are not meeting the demands of their profession. The disparity between the classrooms for which teachers are being prepared and the actual classrooms of today is reinforcing the need for changes in teacher preparation programs.

\section{Purpose}

Our field of teacher preparation must work to better understand the demands on contemporary teachers and systematically adjust our practice in light of these understandings. This process cannot occur disconnected from the contemporary classroom. If we are to create meaningful and lasting reform, we must possess a deep understanding of the current issues facing a science classroom teacher (Anderson \& Mitchener, 1994). This requires that the people we are seeking to develop, teachers, be at the heart of our inquiry processes (Lather, 1986; Mason, 1998). As teacher educators, we must work collaboratively with beginning teachers and face a ceaseless confrontation of the experiences in their daily lives in a mainstream classroom.

Our study was based on the belief that the understandings needed to adjust teacher preparation - understandings of the nature of becoming a middle-level science teacher that meets the needs of ELL children in the mainstream classroom-must come through a reciprocally educative process; that is, a process in which design, data, and theory emerge, with the data being generated from people in a relationship (Lather, 1987). Therefore, we developed the following feminist action research study that centered on the process of collaboratively and actively becoming a teacher that meets the needs of ELL children in an actual middle-level science classroom.

The purpose of our study was to develop an understanding of the experience of becoming a teacher that can create a mainstream science classroom conducive to the needs of ELL learners and to use this understanding to improve our practice, science teacher preparation. To capture the essence of the experience, the process was guided by the question, "How does a beginning middlelevel science teacher develop as a teacher of ELL learners in the mainstream classroom?"

\section{Guiding Literature}

\section{Teachers' Roles in Exploring Inclusive Practice}

The science teacher is one of the most critical components in creating science classrooms conducive to the needs of ELLs (Fradd \& Lee, 1999). As we worked to define the 
teacher's role in our project, we identified several roles that were being emphasized in the current literature.

Fradd and Lee (1999) examined teachers' role as the facilitator of learning within the classroom. They looked upon teachers who took on the identity of knowledge-transmitters. These authors pointed out that teachers who take on this role tend to view their students as limited in knowledge. It may be better for the teacher to take on a facilitator role, which would allow the students to engage in individual empirical inquiry. One teacher in their research project took the role of a conductor in her classroom. She pretended to be the conductor of an orchestra. Her transformation into the conductor of the classroom generated student involvement in active learning.

Mason (1998) involved teachers in the role of researchers. Together, their team explored the use of oral and written tools in science classrooms as a means to facilitate cognitive development. They determined that the students benefited from the classroom activities. For example, the activities helped the students with thinking and reasoning in the collective and individual sense. Also, the teacher considered that the organized use of talking and writing science activities is very beneficial to student learning.

Teachers have been encouraged by Rakow and Bermudez (1993) to actively explore their own interactions with ELLs. There are certain cultural values and systems that do not neatly interact with American values. These authors stressed the importance of having teachers inquire into their own value systems to bring consciousness to the classroom. An ELL student will be keenly aware if their teacher does not encourage them to succeed in science. These subtle messages will have negative effects on the achievement of ELL students. They also pointed out that a multicultural approach to science cannot take a simplistic view. Language differences have been an obvious deterrent for some students and for academic achievement; however, it is not the sole barrier to effective communication and learning in the classroom. For many Hispanic students, cultural beliefs and values, the influence of home, learning styles, and other factors play an important role in classroom learning. This holistic approach to science classroom instruction can provide effective results for teachers and students.

The science teacher's role in our inquiry was guided by these inquiries. We sought a teacher who would become a member of the research team, maintain a lead role in facilitating classroom interactions developed by the team, and be willing to inquire into his/her personal understandings of creating an inclusive classroom.

\section{Integrative Teaching Strategies for the Inclusive Classroom}

We found a wealth of valuable data on effective science teaching strategies. The amount of literature on effective science teaching strategies for ELLs is not as extensive, but is increasing. We sought to build on the knowledge provided by this literature.

The work of Vine (1997) and Driver, Asoko, Leach, Mortimer, and Scott (1994) informed our decision to utilize social learning situations that paired ELL with non-ELL students. Vine (1997) advocated the pairing of ELL with non-ELL children. Peer learning provides opportunities for ELL children to gain insights into the English language. At the same time, non-ELL children are afforded opportunities to experience a different language and culture. Driver et al. (1994) discussed learning science by means of social construction. One way in which the actual construction of understanding, including scientific understandings, was created when persons engaged in social activity with one another about problems or tasks. Learning is considered the process through which more skilled members introduce others to cultural tools. 
The Cheche Konnen Project identified several concerns of education for ELL students. Roseberry, Warren, and Conant (1990) concentrated on the promotion of science to students that have never studied it before and who may have had little schooling at all. The aim of this project was to provide the students with the opportunity to practice science as experienced by scientists. Hands-on approaches were encouraged that involved the students with the planning and implementation processes of research. Students designed their own theories and conducted data analyses. ELL students learned the correct definition and pronunciation of hypothesis, but they also gained a personal understanding of the word. It was applied in a meaningful way to their everyday experience. It did not remain an elusive, abstract concept.

Bautista (1997) sought to capture the rich background of educators successfully teaching ELL students science. Through surveys and focus group discussions, researchers identified effective teaching methodologies. These methodologies included the use of pictures and physical models, flashcards for important vocabulary, and use of background knowledge of the ELLs. The findings from this study are consistent with the recommendations put forth in the Cognitive Academic Language Approach (Chamot \& O'Malley, 1994), an approach we had previously incorporated into our methods courses.

This literature became the most influential to our efforts in developing and implementing classroom interactions/activities. This practice was then explored to enhance our understanding of preparing teachers to utilize these integrative strategies.

\section{Theoretical Perspectives}

\section{Inclusive Science Teaching}

Our study explored the process ofcollaboratively creating a classroom more conducive to the needs of ELL children. To work toward this common goal, we had to first assure that we were indeed working toward a common goal. Educators can approach topics of diversity from vastly different theoretical perspectives (Willis, 1996). This is especially true of educators working within different professional arenas (i.e., science education and literacy education) who are working in relationship with classroom teachers (Franklin \& Buck, 2002). We understood that theoretical differences could hinder, if not destroy, any attempts at classroom improvements. In light of this, we first sought to clarify the theoretical underpinning that would guide the educative process we were to go through together.

In her exploration of the theoretical perspectives guiding work on gender issues in mathematics education, Willis (1996) came to describe four possible approaches in this area: (a) remedial; (b) nondiscriminatory; (c) inclusive; and (d) socially critical. We related these perspectives to our impending study on meeting the needs of ELL children in science and, ultimately, developed a combined perspective that guided our efforts. A summary of this process follows.

Approaching our task from the first perspective just listed, remedial, would mean starting with the understanding that the curriculum (what is taught and how it is taught) is a given. We would hold the assumption that the ELL children are lacking the experiences, skills, and understandings that children from the majority population have that enable them to succeed within that curriculum. We would work together to understand the process a beginning teacher goes through in seeking to provide these children with what they lack in such a way that does not hinder the mainstream classroom. In contrast, approaching our task from the second perspective, nondiscriminatory, would mean starting with the understanding that what is to be learned is a given, but how it is to be taught and assessed are not. We would hold the assumption that many of 
the contemporary pedagogical practices are favoring one group of students, often at the expense of ELL children. We would seek to understand the process a beginning teacher goes through to accurately identify and change the strategies that prevent the ELL students from succeeding in the mainstream science classroom. Approaching our process from the third perspective, inclusive, would mean starting with the understanding that the curriculum is not static and is subject to change. We would hold the assumption that it was the curriculum that often prevented ELL children from succeeding. We would seek to provide the children with a combination ofcurriculums that better matched their own social groups' experiences and needs. If we approached our task from the critical perspective, the fourth perspective just listed, we would seek to understand how a beginning teacher identifies social injustice and proceeds to disrupt the position and privilege the dominant culture has over persons for whom English is a second language. We would seek to understand how a teacher can help the ELL children to develop an understanding of how science is often used in the interest of the dominant group and ultimately teach them how they could use science to further the interests of social justice. As Willis (1996) pointed out:

... the four do not represent a set of discrete categories. Thus, you might take a socially critical perspective and yet, at the same time, recognise that, because of the way in which the curriculum currently is constructed, some strategies located within the remedial perspective can be warranted for some children.... (p. 50)

Often, lived practices are a combination of perspectives. This was the case for us. Apart, we would have represented many different perspectives, especially if we were viewing classroom practice as outsiders. But, working in relationship with the data being generated from our experiences as a beginning teacher, we had to seek the perspective that would best fit that experience (i.e., we had to acknowledge that, although one member of the team may have wanted to create curriculum that enhanced social justice, a classroom teacher, especially a first-year teacher, would not be free to approach this task from that perspective). Ultimately, we decided that the best approach would be to take an inclusive perspective that recognized that what is to be learned was set by the school district; although it would be possible to bring in additional curricular materials and adjust the way the curriculum was delivered.

In this action research process, we sought to understand what a beginning teacher must do to create an inclusive classroom that utilizes nondiscriminatory teaching practices that can foster success for both ELL and non-ELL students. Our definition of success acknowledged that the children had to meet district objectives. However, we also acknowledged that success meant better addressing the experiences, interests, and needs of the ELL children.

Research orientation. Lather (1986) pointed out that feminist research methods assist researchers and educators with the somewhat tenuous task of addressing social issues while providing a means to identify solutions that improve overall equality. The intent must be to use the research process to help participants understand and change their situation (Lather, 1988). Therefore, feminist research methods concentrate on themes and interpretations instead of prediction and control. This inquiry was approached not from a process-product approach, seeking to correlate processes or products to results (Shulman, 1986), but rather by focusing on developing a genuine understanding of the experience of the first-year teacher working to create a classroom that meets the needs of ELL students. We sought to develop this understanding by going through the experience with her and then using that understanding to empower her to succeed in her practice and empower ourselves to succeed in our practice-teacher development. We defined success by our vision of inclusive science education (described earlier). 
Reinharz (1992) created a categorization system for feminist research. This system describes five types of feminist research encompassing many different techniques. One type of research is action research. This type of inquiry involves a simultaneous focus on research and evaluation. The efforts of the inquiry are continually refined in light of a progressive analysis of the findings. The goal is to create change from the ideas and experiences developing throughout the project. A second type of research is participatory or collaborative research. In this type of inquiry, the participants of the study make the decisions about the study format. The participants have a combined researcher/subject role. The process is aimed at creating change by adjusting the role relations of people involved in the project. The line between researcher and research subject disappears. Prevalence and needs assessment research, a third type of feminist research, seeks to determine the number of people with a specific need or experience. Fourth, evaluation research evaluates the effectiveness of an action in meeting the intended need. The fifth type of feminist research described by Reinharz is demystification research. This type of inquiry focuses on obtaining new knowledge about an oppressive act or understanding. The focus of this type of research is on raising the consciousness of groups by challenging those with a vested interest.

The present study was a feminist action research project with influences of participatory or collaborative research. Throughout the process, we asked questions, collected and analyzed data in light of those questions, adjusted practice, and then asked more questions. The project was guided by the experience itself as well as the ideas of all members of the research team. The process was a part of the everyday life of a first-year teacher. The process included district objectives, standardized tests, parental demands, peer pressure, and influences from the previous night's television shows. This teacher was a full member of the action research team. The lines between teacher and researcher were eliminated; the teacher was not acting in isolation, being viewed by persons in authority. She was a member of a peer group that also included teacher educators. Together, we planned and evaluated classroom activities and data collection strategies. We evaluated individual students' progress and analyzed data.

\section{Method}

We developed a feminist action research project with influences of participatory or collaborative research. This methodological approach was utilized to understand the experience of a first-year middle-level science teacher working to create a mainstream classroom conducive to the needs of ELL learners and to use the resulting understanding to improve our middle-level science teacher preparation program.

\section{Participants}

Our research team included one first-year middle-level science teacher, one science teacher educator/researcher, one researcher of English-as-second-language learners, and one graduate assistant. To better connect our experiences to those of a student exiting the teacher preparation program that would be adjusted in this process, the teacher was recruited from a recent pool of graduates from that program. The first-year teacher was selected due to her desire to become involved in the project and her assignment to a diverse middle school. Also, due to the participatory nature of the inquiry, another critical criteria used in the selection process was our favorable assessment of this teachers' ability to see herself as a full member of the research team. To allow the reader to follow the analysis of one member of our team, in what follows we refer to this member as "the teacher" or "she." 
To better understand the process of creating a mainstream middle-level science classroom conducive to the needs of ELL learners, we believed that the students had to be given a voice in the process. In light of this, all students in one section of sixth-grade science were given both a student and guardian consent form to participate in the study. We had these forms translated into three different languages. From the pool of students who returned an agreement to participate for both themselves and their guardian, we selected nine student participants. The student participants included five ELL learners and four non-ELL learners. The first languages represented in this group included Russian, Arabic, Kurdish, and Farsi. Four non-ELL students were selected from a group of consenting students and followed to monitor the effects the action plan had on non-ELL children. The selection of these non-ELL students was guided by efforts to match general student characteristics to participating ELL students.

\section{Context}

The classroom was not designed for the study. Our research project involved an actual firstyear teacher with an initial teaching assignment that involved ELL learners. The location was the teacher's initial school assignment. The class section was selected based on classroom population (including a substantial percentage of ELL learners) and class schedule. The class schedule was selected based on available time for the observers to get set up and exit with minimal disruption to school routine.

Our school site was located in a midwestem school district of 30,688 students. Included in this was a minority population of $13.7 \%$. The school itself, consisting of 521 students, had a minority population of $35.9 \%$, the largest group being African Americans (15.3\%). The ELL population was 14\%. Within this population there were 11 first languages represented, including Vietnamese, Spanish, Arabic, Kurdish, Ukrainian, Serbo-Croatian, Russian, Bosnian, Korean, Albanian, and Farsi.

Our classroom population was 20, with 11 boys and 9 girls. Included in this population were five ELL students (two girls/three boys), five children identified as severely learning disabled, and two identified as behaviorally disabled.

The curriculum covered during our study was based on district objectives. Although initial observations occurred during a unit on electricity and magnetism, the majority of the observed classroom time was spent on human biology and health. All student interviews focused on their understanding of human biology and health. The teacher in our study broke this section of the curriculum into three study units. The data collection plan was centered on this design. The three units of study included: (a) how the body is organized and stays in balance; (b) body systems; and (c) the immune system and common diseases.

\section{Data Collection}

The design of our study called for us to be participant observers. "Observational data, especially participant observation, permits the... researcher to understand a program or treatment to an extent not entirely possible using only the insight of others obtained through interviews" (Patton, 1990). By becoming involved in the case, we were able to feel the same emotions and constraints of each other's circumstances.

As participant observers, we collected the data by being in the field on a regular basis and participating in the actual process of education. The data sources we utilized included: (a) meeting notes; (b) classroom lesson plans; (c) classroom observations; (d) teacher interviews; (e) student interviews; and (f) student work. 
Our overall project was divided into three sections, based on the three units of study. We came together on a pre- and post-unit basis. The pre-unit meetings focused on developing plans and strategies for the upcoming unit. The post-unit meetings focused on reviewing and analyzing the data collected during the unit of study, summarizing the results, and developing implications for future units. The pre- and post-unit meetings were conducted simultaneously between the first, second, and third units to allow the suggested implications to be applied to the planning of the next unit. Detailed notes were taken at each meeting and later forwarded to each member of the team. Following the pre-unit meetings, the teacher developed a detailed unit outline and timeline. This timeline was utilized to set up the observation schedule.

The teacher and students were observed 37 times during a 5-month period. The classroom observation instrument we utilized was a modified version of the teacher education instrument developed by the Systemic Teacher Excellence Preparation program at Montana State University (STEP, 2001). We determined this was the most appropriate instrument in light of our project goals and made minor revisions to accommodate for context. Prior to the start of the inquiry project, we validated the observation procedure by simultaneously observing several of the middle-level sections that would be the focus of the study. The observation data were reviewed and the procedure was adjusted. During the study, two members of our team completed the observations simultaneously. One observer was assigned to focus mainly on the students and the other focused on the teacher, although both observers made notes on the overall experience. Our observations focused on the classroom environment, instruction, ELL and non-ELL student engagement, student comments/questions, teacher comments/questions, and evidence of learning.

The teacher was interviewed pre- and post-project. The interview questions were based on the goals of our project and were completed in a semistructured format. Sample questions included: (a) What are the beliefs upon which you base your teaching? (b) How do these beliefs relate to the teaching of second-language learners? (c) Do you currently make changes in your teaching for second-language learners? (d) What kind of skills and knowledge do you think they (the students) will need? The research assistant completed the interviews.

Lee, Fradd, and Sutman (1995) pointed out that students who have limited language skills often give a false impression that they have no science knowledge. Understanding that we were susceptible to a false impression by relying solely on written work, we sought to expand our database with interviews in which the students could explain concepts in their first language, or use visuals and/or gestures. Each participating student was interviewed three or four times throughout the project. A total of 33 interviews were conducted. The students were asked questions such as: (a) How does the body protect itself against germs? (b) Can you tell me why you may get a fever? A translator was available for all interviews, but ultimately only needed for the interviews of one student. In several interviews, the visuals utilized in the classroom were provided to aid the student in their explanation.

All student work that the teacher collected during the action research project was copied and became part of the data set. In addition, some student work that was not collected but determined by either the teacher or observers as integral to the project was requested from students and copied. An example of this is student notebooks. The written student documents collected included an extensive amount of student worksheets, notebooks, homework, quizzes, and tests. The teacher's lesson plans, overheads, and unit outlines were also collected and copied.

\section{Validity}

Lather (1986) discussed the importance of assuring the validity of research committed to improving social and educational practice. She reconceptualized validity and offered guidelines to 
follow within openly ideological research. Her guidelines were used to develop our inquiry. The guidelines include triangulation, construct validity, face validity, and catalytic validity.

\section{Triangulation}

Triangulation of sources is apparent in our inclusion of a middle-level science teacher, teacher educator, ELL teacher educator, ELL students, and non-ELL students. The sources also included different settings: classroom and planning meetings. The triangulation of methods is found in our use of interviews, observations (classroom practice and planning session), and written document review. We addressed triangulation of theories by including, as full team members, a science teacher educator, an ELL teacher educator, and a first-year teacher. Each of us brought a different theoretical construct.

\section{Construct Validity}

Construct validity was strengthened by our efforts to continually refine our study in light of a progressive analysis of the findings. Reinharz (1992) explained the work of Smail, Whyte, and Kelly, who initiated an action research project with girls in science:

They achieved (their) goal by a fluid approach that they constantly evaluated, rather than by a "traditional" research project where the design is thought out at the beginning by the research team, implemented in a carefully controlled way in the schools, and finally evaluated. Their goal was to create changes that would stem from teacher preferences, ( $\mathrm{p}$. 180)

In our study, the fluid approach was utilized to create change that originated from the actual experiences and ultimate preferences of all participants. Our research on the experience of meeting the needs of ELL children in the mainstream middle-level science classroom was guided by the simultaneously conducted evaluation, reflection, and adjustment to our effort.

\section{Face Validity}

Face validity was integral to the process. The first-year middle level science teacher was a member of the research team. The data collected on classroom practice, interviews, and meetings were shared and collaboratively analyzed with the teacher. The final analysis and implications were shared with the full research team for review and input.

\section{Catalytic Validity}

Lather (1986) argued that feminist research must have a reality-altering impact and needs to consciously channel this impact so that the respondents gain self-understanding and selfdetermination. Our research process not only informed us in a way that was not previously expected, but the teacher made several statements as to the dramatic change in practice that occurred as a result of her involvement in the research process. This is further elaborated on in the Findings and Implications subsection of this study.

\section{Data Analysis}

We analyzed the data immediately after collection to allow it to inform our action plans. All members of our team reviewed the cumulative data from classroom observations, teacher and 
student interviews, and written documents. The feminist action methods allowed for the evaluation process to occur simultaneously with the project. Reinharz (1992) discussed the "series of feedback loops" in her text, and its importance at changing and directing human behavior. Our team meetings of the project provided opportunities to identify approaches that would improve education outcomes for this science classroom. During the active observation period, six meetings were held to discuss emergent themes, the similarities and differences in interpretations, and future directions for practice. The meetings allowed us to take advantage of information that did not appear to be beneficial to the inclusive classroom. This continuous analysis became part of the field notes and, as such, became additional data to be analyzed at the completion of our project.

After the observation period ended, the first-year teacher wrote a collective summary of the experience. This summary became part of our cumulative set of data. Our cumulative data were then analyzed in a series of steps. As a group, we decided that each member would complete an individual analysis of the data. Thus, each member of our team was sent a copy of the final set of data. We read the data multiple times, identified categories, coded the data, and made statements about the categories utilizing references to the actual data as support. Each of us submitted a report of our findings to one designated team member. This team member synthesized the reports. Our final data sets were teaching strategies, student achievement, and professional growth. The internal make-up of each category was structured for overall consistency and change over time. The synthesized report was then evaluated for completeness by testing for: (a) internal and external plausibility; (b) inclusivity of data; (c) reproducibility; and (d) credibility (Cuba, 1978). Reviewing each category internally for consistency and externally to determine if the set of categories comprised a complete picture of the experience was a test for internal and external plausibility. Inclusivity of data was reviewed by determining if there was any coded information that remained unassigned to a category and determining if the set referenced the nature of the investigation. Seeking further input from the entire team tested reproducibility and credibility. This was completed by sending a draft of the synthesized report to each member of our team prior to the final collaborative meeting on the project. During the final meeting, we discussed the findings and, together, made a final report of the findings.

\section{Findings}

\section{Teaching Strategies}

Data were collected using meeting notes, observations, student interviews, and written documents to provide insights into the teaching strategies our beginning middle-level science teacher effectively utilized to create a mainstream classroom that was conducive to the needs of ELL learners. All members of our research team reviewed the wealth of data, and a collective statement of the findings was noted. Of all of the instructional strategies attempted in our teacher preparation program, three were found to be effective on the basis of our data analysis.

The first strategy was the use of authentic visuals. At the initial team meeting, we set a goal to utilize more visuals in the teaching process (Meeting Notes \#1). The teacher member of our group incorporated several visuals into her practice. This strategy proved to be generally effective; however, there were some detrimental effects. Examples of effective visuals were batteries, light bulbs, wires, and pictures of real human organs. The ELL students were actively involved in the discussions that included these visuals and successful in the subsequent activities (Observation Notes \#4 and \#14). The negative consequences occurred when the visuals were not directly representative of the concept being discussed. A critical look at some of the visuals with the teacher revealed possible misconceptions that could occur for someone not able to grasp a verbal 
explanation of the relationship between the visual and course content. For example, a dog's lungs were used as a model for human lungs. The demonstration included extensive use of verbal clues to indicate that the lungs were not human and how a human's lungs would differ, although many ELL students were not attentive during the verbal discussion (Observation Notes \#14). Even with extensive probing, the ELL students were not able to explain how the lungs differed (Interviews \#9-12). With feedback such as this, derived from observations and interviews, the group discussed and refined the strategy over time. Increasingly, the visuals the teacher incorporated into her activities better portrayed the concept being discussed. Pictures, books, and materials that would provide an authentic context without heavy dependence on language were utilized to provide students with a variety of cues within the activities. One particular activity found to be effective was the use of models of human bones, which were exact replicas, along with picture books of bones (Observation Notes \#20). The average grade for the ELL students on the subsequent assessment was a $\mathrm{B}$, which was the same average grade as the non-ELL students (written documents). Overall, the concepts conveyed via authentic visuals were often mentioned by the children in the interview process and were most often responded to correctly on classroombased assessments.

Hands-on activities, in which the students are involved in the planning of the activity, have been demonstrated to benefit ELL children (Roseberry et al., 1990). Such activities were emphasized and practiced in this first-year teacher's preparation program, and thus the implementation of these strategies became something we sought to explore with her (Meeting Notes \#1). Initial observations verified that, in contrast to the off-task behavior noted during the majority of time the teacher spent on the overhead or worksheets (Observations Notes \#4- and \#9), time she spent on hands-on activities resulted in active engagement by the ELL students (Observation Notes \#3 and \#14). However, during these hands-on activities, it was also noted that the ELL students seemed lost and somewhat panicked. For example, in one hands-on activity on magnets, observations showed Student 1 was "very engaged in activity," but when it came to filling out the lab sheet she became confused and the resource teacher came over and ultimately gave her the answer sheet. A few minutes later. Student 1 was no longer active and "insteadcopying answers from sheet" (Observation Notes \#14). When expected to fill out a sheet on the activity or to answer questions, the ELL students began to desperately look around, noted the observable behaviors of their classmates, and copied these behaviors. For instance, during another activity, an ELL student became confused during the lab activity and let her partner totally take over the task of filling out the lab sheet (Observation Notes \#15). This demonstrated to us that students were mimicking behaviors and letting others complete the parts of the activities that reinforced content understandings associated with the tasks, but not developing the intended understandings. Thus, efforts were made to help the first-year teacher make the hands-on activities more minds-on for the ELL students. After discussions, the team decided to foster more cooperative experiences in which the ELL students worked with non-ELL students on projects designed to have them explore and discuss the concepts first, discuss the procedure for developing an understanding, carry out the processes, and discuss the conclusions (Meeting Notes \#2). The teacher was able to effectively initiate such activities and, ultimately, we found this strategy to be effective, but not until we came to the needed understandings of how to help her successfully develop cooperative groups that fostered learning for ELL children (examined in what follows).

In working together with our first-year teacher we found that establishing workable cooperative groups was the most effective method for ELL student learning. However, the establishment of such proved to be much more difficult than was originally thought (or taught). Initial observations revealed that, although she incorporated the cooperative learning strategies acquired in her teacher preparation program, very little interaction or cooperation occurred. 
Observations revealed that the ELL students did little more than continue to mimic what their nonELL classmates were physically doing or did not interact with classmates electing to wait to interact with the teacher. For example. Student 2 was very reluctant to work with the group; instead, he looked toward the teacher, waiting to catch her eye and receive one-on-one attention (Observation Notes \#13). Plans were developed to include more steps in the cooperative process that required group discussion. For example, the teacher developed a "tea party activity." In this activity, the students were asked to "mingle with the other students and communicate their information with each other" (written document). Indeed, observations on the second portion of this project showed that more discussion was occurring; however, the cooperative learning groups increasingly influenced the classroom behavior of the ELL students. This proved to be a good consequence in some cases, but negative in others. For example, observations showed that Student 3 was working very well on the activities, but Student 4 was now "fooling around throwing paper at others in group" (Observation Notes \#1S). We determined that the deciding factor seemed to be the dominant personality in the group-either a positive or negative role model. A discussion emerged about the make-up of the cooperative groups. It was determined that an effort should be made to put a positive, dominant personality in each group (Meeting Notes \#2). However, through the next observation period, it was discovered that the ELL students did not always become swayed by the positive, dominant personality; sometimes they were easily distracted by a less dominant, negative personality. For example, a quiet non-ELL student that was often found offtask swayed one tentative, reserved ELL student that had been making progress. During the observation period that followed the restructuring of cooperative groups, this ELL student was noted to be throwing tape back and forth with the non-ELL student during the class and copying his quick/short answers on the worksheet when the teacher started to collect them (Observation Notes \#23). We were now finding ourselves helping this teacher to foster classroom management problems. So, a decision was made to work with her to match personalities in a way that dominant students were matched with other dominant students, and the more reserved students grouped with similar peers (Meeting Notes \#3). This increased the level of engagement for all students, and seemed to eliminate the withdrawal of the more tentative, reserved students, and also increased the success of learning that was visible through student comments and interactions. It seemed that, as more suitable groups were established, the verbal interactions and communication increased significantly (Observation Notes \#33, \#35, and \#36).

Not all of the strategies we explored with the first-year teacher proved to be effective for the ELL students. For example, the use of children's books on the topic being explored did not seem to appeal to any of the ELL children and seemingly had little impact. During the use of these texts, the ELL students would be found drawing pictures, playing with objects, or being disruptive (Observation Notes \#20, \#23, and \#26). The same observations showed the non-ELL student participants paying attention during the reading of the books. As a result, the average score on the quiz that followed this period was a D+ for the ELL students and an A- for non-ELL students (written documents). Other strategies not effective for ELL students included symbolic visuals, complex games, and a demonstration of the process of taking notes using the overhead. For example, one section in which the process of taking notes was used extensively resulted in an average test score for non-ELL students of B+ and D- for ELL students (written documents).

In conclusion, we found that successful use of authentic visuals, hands-on activities, and cooperative learning led to a growth in understanding by the ELL students. This growth is further evidenced in the next subsection. However, over the course of this experience, we found that these strategies involved complex structural considerations that were not a part of this teacher's preparation. Some of these considerations, such as evaluating visuals for possible misconceptions that may be conveyed, were understood by the more experienced team members, but the fact that 
they would not be understood by a beginning teacher was missed. Others, such as the complex personality considerations, specifically for ELL learners, involved in establishing cooperative learning groups for hands-on activities, were not understood by the experienced team members and found to be mostly unexplored assumptions for the entire team. In addition, we also found that not all of the strategies presented in the teacher's preparation courses were appropriate for her specific context and that she needed to be able to determine what "works" for a given situation. This raises additional questions about this teacher's preparation (see Professional Growth subsection).

\section{Student Achievement}

Classroom observations and written document collections focused on students 9 mastery of the content knowledge. However, these processes are limited by the constraints of working with children whose language skills are limited (Lee et al., 1995). To increase the reliability of our data on content mastery, students were also interviewed on a pre- and post-unit basis about their knowledge of the content covered in the unit. These interviews were semistructured and conducted by a trained interviewer, and an interpreter was available. Data analysis revealed that the ELL students did increase their level of understanding of human biology in this inclusive mainstream classroom, but their rate of development did not match that of non-ELL students nor the research team's and the district's expectations for all students.

The first interview showed that the ELL students had little knowledge of human biology. The majority of interview responses revealed that the students did not have the necessary prior knowledge to even decipher the question. Student responses included: "Uhm, I don't know what to say" (Student Interview \#4); "What was the question?" (Student Interview \#1); "I think it's [bone] made of...I don't know” (Student Interview \#5), “[What's occurring inside your body] something that pumps" (Student Interview \#3)', and "I don't know, I forgot" (Student Interview \#3). One student answered about his brother washing cars (Student Interview \#5). When students could determine that the questions were about their body, they responded with body parts they could see and touch-"Toes, eyes, mouth" (Student Interview \#3). This knowledge was shared with our research team and an effort was made to emphasize the prior understandings necessary for the topic while it was being studied. For example, the teacher member of our team explicitly noted to the students that the subject was about their body and emphasized the major parts prior to talking about their functions. Observations showed us that this scaffolding technique, explicitly designed around the ELL children's responses, resulted in ELL students becoming more engaged in classroom lessons.

By the second and third round of interviews, after the completion of one or two units of study developed by our action research team, the ELL students began to exhibit a more defined knowledge of the human body. They appeared to understand most questions, even if they could not answer them accurately. Although many of their questions would be considered inaccurate, they demonstrated an effort to utilize a growing understanding of human biology to construct their answers. For example, they mentioned more organs and some process information in their explanations. When asked about the organs that help the body filter out waste, one student reported that "The bad stuff.. .the large intestines, Um, move. Um, breathe" (Student Interview \#16). Prior to instruction, this student's responses on any questions on the body were, "I don't know," "Uhmm, I don't know," or a refusal to give a verbal response (Student Interview \#4). Another student responded “... eat(ing) ice cream and you drink milk" (Student Interview \#20) is the process through which the bones grow. There was also a significant increase in the number of correct responses. When asked why we need skin on our bodies, one student responded "To 
protect your body... from germs and dirt, those stuffs" (Student Interview \#20). When asked about the digestion system, one student responded:

It goes through the esophagus, and it goes through your stomach. And it moves into liquid, then it goes into your small intestine, and it breaks it up even further into small pieces. Some of it goes into blood and some goes into large intestine. (Student Interview \#17)

Other ELL students matched this understanding of the digestive system. During the final interview, the students also demonstrated that there was an understanding of the immune system. All of the students knew how germs entered the body.

The level of content mastered was still at a more basic, concrete level. For example, digestion and the organs of digestion and how they worked appeared to be more commonly mastered. These concepts were directly related to eating, nutrition, etc., and the organs, and could be visually represented during the active phase of the project. More abstract concepts such as cells, allergies, and diabetes were extremely difficult to place in a relevant context with pictures, and the findings revealed that learning was minimal at best on these concepts. The areas of growth involved science concepts that had an obvious connection to the lives of the students.

The non-ELL students started out with more content knowledge. They could name some body organs and had a general sense of some body functions like digestion, circulation, and sweating. They did not understand the processes very well but did have a sense that a process was occurring. Throughout the units of study, students were able to give thorough and correct responses. They could give examples when prompted by the interviewer. This increase in understanding of the nonELL students occurred in a classroom that was making deliberate efforts to improve the learning of the ELL students.

A review of the written documents supports findings from the interviews. The ELL students illustrated a growing understanding of human biology and health. However, their understandings, in many cases, were still naive and did not match the pace of the non-ELL students despite efforts to teach them in a mainstream classroom. Likewise, the non-ELL students continued to grow and develop in a classroom that was becoming more conducive to learning for ELL children.

\section{Professional Growth}

The teacher member of our group was interviewed before and after the project. In addition, her input and efforts were collected through meeting notes, observations, and personal reflections. These data were utilized throughout the process and cumulatively analyzed at its completion. It is critical to note that this teacher was a member of the research team. As such, she took part in this analysis and added meaning throughout the process, enhancing the face validity of the research project. The final analysis showed that she came to realize that meeting the needs of ELL learners in the mainstream classroom was even more complex than expected; she was not fully prepared to teach these learners, but was able to improve her practice with the aid of student and peer feedback; and she had some unexplored assumptions about the ELL students that she began to question as she came to better understand them through the feedback process.

The teacher researcher came to this project with the belief that meeting the needs of ELL learners in the mainstream was a difficult task for the teacher. She noted, "I have the same goals for them, it's difficult to do, it's a lot of hard work to do" (Teacher Interview \#1). However, she was optimistic that she was prepared for the task. She came from a teacher education program that provided her with the knowledge of strategies to use with such learners. Her confidence was strengthened by the fact that she was taking the action research team with her into her first year of teaching. However, over the course of the year, she came to realize that meeting the needs of these 
ELL children while continuing to keep a focus on meeting the needs of the non-ELL children was even more complex than she imagined. It was not a matter of her being a beginning teacher who needed to learn how to accomplish this task, but rather the matter of an entire team of professionals trying to discover how or if it could be done. Over the course of the project, she realized that, although she understood some of the recommended strategies for teaching ELL learners (e.g., cooperative learning), there were strategies within those strategies that she did not understand. For example, "I tried to use pictures, but if they didn't know what pollen is in a picture of a piece of pollen, is a microscopically enlarged image, well, that doesn't give them much context" (Teacher Interview \#2). Without the push and type of feedback the project afforded her, she may have abandoned some strategies very quickly in her practice. This seemed like the path to take as she experienced the initial failures of our efforts: "You look at the huge difference, the huge mountain you're trying to overcome with them. I mean I even limited out a ton of vocabulary, and I still felt overwhelmed with how much I was expecting them to learn" (Teacher Interview \#2). However, she did forge ahead and, together with the other researchers, soon learned how to construct situations to better meet the needs of the ELL learners. She also came to understand that the strategies she thought she had brought to the classroom would not work for all ELL children. Within the study group, she got to truly know the ELL children and how their needs differed within this subgroup. In her final interview, she elaborated on how the ELL children compared and contrasted, determining that they had similar and different learning needs. She had to learn how to meet the needs of each individual ELL child, in addition to the other children in the classroom.

Although the initial stages of analysis were somewhat intimidating in that they showed that the ELL students were not coming to understand the sought after concepts, the teacher soon came to look forward to and value the feedback process. "The feedback about the student learning helped me brainstorm additional ways to present information that would encourage student communication" (Teacher Interview \#2). It was within this trial and error that the teacher discovered that, although the process was much more complex than anticipated, she could improve her efforts to teach science to the ELL students. The teacher ultimately credited the peer and student feedback with her improved skills in such areas as developing and fostering cooperative learning in heterogeneous groups, presenting information that would encourage student communication, and using visual information. She indicated that, "overall, without this type of feedback, the student learning and engagement of many students (ELL and the more reserved, non-ELL students) would not have developed to the extent that it did" (Teacher Interview \#2).

By taking part in interviews on authentic practice and in research that provided her with detailed feedback on the students in her classroom, the teacher member of our group came to question what she believed about teaching ELL students in the mainstream classroom. First, she came to question an unexplored assumption that, although many ELL students could provide rich cultural experiences in the science classroom, they could not provide rich scientific skills. However, information she received throughout the research process emphasized to her "the apparently more mature observation skills of many of the ELL students, as they were able to understand what we were trying to accomplish just by watching, when the language was not comprehendible" (written document). This is a common strength of the ELL students that she would like to try to utilize to help develop that scientific skill in non-ELL students.

\section{Conclusions}

As an action research team, we spent 5 months actively working to create a classroom more conducive to the needs of ELL learners. Together, we fostered the academic growth of the student 
participants while coming to a more developed understanding of the efforts a beginning teacher needs to take to teach in a contemporary mainstream science classroom.

As a result of our educational efforts with this first-year teacher, the second language learners did demonstrate an increased understanding of the science concepts covered in the science class. The level of content that was mastered was still at a more basic, concrete level. The learning of abstract concepts, such as cells and allergies, was minimal. The areas of growth had an obvious connection to the lives of the students. Unfortunately, we found that the academic growth we were able to foster was not as large as the increase in understanding for the non-ELL students, and not enough to satisfy district objectives and expectations-an expectation of the district for the classroom teacher and thus for the entire team. The non-ELL students did increase their understandings of the course objectives. This development occurred in a classroom that was actively being restructured to better meet the needs of the ELL learners. This demonstrates that the measures we took to create a more inclusive classroom were not harming the nontargeted (nonELL) students.

Our efforts support the findings from the literature on the use of hands-on activities, cooperative learning, and visuals for ELL learners. However, we came to realize that this literature includes many unexplained or unexplored understandings. In terms of unexplained understandings, the educational research on teaching ESL children in the mainstream science classroom is often completed by experienced teachers/researchers and often communicated to other experienced teachers/researchers. Presenting the same information to beginning teachers is often not sufficient because they may not hold prerequisite understandings. Sharing the experience of this first-year teacher has shown us that we need to provide more literature specifically for the developmental level of beginning teachers. Also, by looking at practice through this beginning teacher's eyes, we have come to question some of the unexplored understandings inherent in our own research, such as the complex personality considerations involved in establishing successful hands-on learning activities in a manner more conducive to ELL learners. In addition, we had to face the reality that some of our most emphasized and valued strategies are not conducive to learning in all situations. We must prepare teachers to question and evaluate the very strategies we present.

In conclusion, the findings in relation to students from our class support those from students described by Lee et al. (1995) as being in contexts that actively support their needs. The ELL students, who started with limited prior experiences and knowledge related to the explored concepts, achieved at lower levels than students with more prior knowledge and experience; however, they also demonstrated important gains. The context we created included a variety of ELL strategies. Those we found to be successful included authentic visuals, hands-on activities, and cooperative learning. However, we found that the utilization of these strategies was much more complex for a teacher than originally thought. For example, we confirmed our belief that cooperative learning experiences benefit ELL learners; however, the development and application of this strategy proved to be much more complex than anticipated. The findings in relation to preparing teachers to better create conducive contexts are critical to our efforts in teacher preparation.

\section{Preparing Teachers to Create a Classroom Conducive to the Needs of Limited-English Learners: Incorporating Authentic Complexity}

The teacher member of our action research team entered the profession from a preparation program that is committed to preparing teachers to teach science to all children. Two of us are faculty members who have previously taken steps to assure that the graduates from this program 
are prepared to teach science to all children. Included in these efforts were preparations for teaching ELL children, as well as the skills and attitudes necessary to become a reflective practitioner. The adjustments we designed and implemented in this program were based on research findings, and we were confident of their validity. However, as we worked with this graduate of our program, we began to greatly problematize our practice. At first, we were working with a beginning teacher who needed to gain experience in selecting and implementing the strategies we gave her, but soon we found ourselves working with this teacher on the complexities of implementing these strategies in a complicated environment. The irony of the project is that our efforts in understanding the task of this teacher to improve our efforts to prepare teachers became the best preparation we could have offered her.

The changing image of the science teacher has shifted from that of technical expert to reflective practitioner (Schon, 1987). Doyle (1990) referred to a reflective practitioner as a person that "first and foremost must be able to inquire into teaching and think critically about their work" (p. 6). As a reflective practitioner, the teacher member of our team did inquire into her efforts on teaching ELL students, deliberated into what strategies would work for these children, implemented those strategies, and documented the results. However, as the efforts continued to produce unexpected results and new problems, the process took her, as well as her "expert" colleagues, into increasingly complex territory. This process consumed the time and resources of an entire team of professionals, including several well-educated and experienced teachers. However, the existence of the action research team and group determination forced her to go beyond initial failure and delve into the complexity as we worked to improve classroom practice. Ultimately, the teacher became more proficient at the skills of a reflective practitioner and was better able to meet the needs of her ELL students, although by her own admission she is still a learner in this area. Also, as teacher educators, we became much more aware of our unexplored assumptions of the task of becoming a reflective practitioner in a contemporary science classroom with diverse student needs-a task we never conveyed as being simple, yet we found it to be one we have oversimplified.

It was the very efforts to understand the task of this teacher that ultimately offered her the preparation she needed to become a reflective practitioner. Unfortunately, as we focus back on our teacher preparation program and the large number of future graduates, we are fully aware that we cannot work with each graduate to the extent that we did in this project. However, our experience has cautioned us against simplifying the efforts to support these teachers (i.e., by having a website or toll-free number). The task that now confronts us is to adjust our program so that it includes the successful components this experience, such as collaboratively exploring the complexity of teaching while eliminating the unattainable components, such as providing each teacher with a research team to take into their classroom. To accomplish this, we could add authentic complexity, such as what we experienced in this project, to our preservice program. However, we have concerns that an accurate portrayal of the task ahead, a task that consumes the time and resources of a group of these students' professors, would overwhelm the novice teachers. To what degree can we complicate the teaching process, aligning the process with real-world practices, without overwhelming these novice educators? Can teachers still maintain a level of self-efficacysomething they need in their future practice (Guskey, 1988)-if we further complicate the teaching task?

One area that we found to show promise is that of the case study. Case-based pedagogy is increasingly common in teacher education (Koballa \& Tippins, 2000). This approach to teacher education models is one that has been used in the medical field for over 100 years (Naumes \& Naumes, 1999). In their book. Learning From Cases: Unraveling the Complexities of Elementary Science Teaching, Tippins, Koballa, and Payne (2002) illustrated how cases can provide students 
with the understanding that there are no clear-cut, simple answers to many educational issues, while also providing them the opportunity to work through real-world cases using discussion from various philosophical approaches, reflection, and investigation. This approach to teacher development shows promise in addressing our dilemma of how to provide all of our graduates with the type of preparation this action research project afforded the teacher member of our group. Providing cases, perhaps constructed from our authentic experience, on meeting the needs of the ELL learner in the mainstream science classroom in our methods courses may allow us to accurately portray the complexity without overwhelming the novice learners in these courses.

This feminist action research project has raised questions as to how to accurately convey the complexity of meeting the needs of ELL learners in mainstream science and then utilize this understanding to better prepare teachers for this task. Our search since the analysis has led us to one promising area for accomplishing this task-case-based pedagogy. Future efforts will determine if such efforts afford the same type of professional development afforded the teacher member in this action research project.

\section{References}

Anderson, R. \& Mitchener, C. (1994). Research on science teacher education. In D. Gabel (Ed.), Handbook of research on science teaching and learning. New York: Simon \& Schuster Macmillan.

Bautista, J. (1997). Effective teaching methodologies for ESL students learning secondary science: Recommendations from the field. In L. McCoy (Ed.), Studies in teaching: Research projects presented at the Annual Research Forum (pp. 11-15). Wake Forest University, Department of Education, Winston-Salem, NC, ED 418942.

Chamot, A. \& O'Malley, J. (1994). The CALLA handbook: Implementing the cognitive academic language learning approach. New York: Addison-Wesley.

Cornell, C. (1995, Winter). Reducing failure of LEP students in the mainstream classroom and why it is important. Journal of Educational Issues of Language Minority Students, 15. [Available online: http://www.ncela.gwu.edu/pubs/jeilms]

Doyle, W. (1990). Classroom knowledge as a foundation for teaching. Teachers College Record, 91, 347-360.

Driver, R., Asoko, H., Leach, J., Mortimer, E., \& Scott, P. (1994, October). Constructing scientific knowledge in the classroom. Educational Researcher, 23(7), 5-12.

Fradd, S. \& Lee, 0. (1999). Teachers' roles in promoting science inquiry with students from diverse language backgrounds. Educational Researcher, 28, 14-20.

Franklin, E. \& Buck, G. (2002). Learning the language of science: A case study of second language learners in a science classroom. Paper presented at the National Association of Research in Science Teaching, New Orleans, LA.

Gersten, R. (1999). Lost opportunities: Challenges confronting four teachers of Englishlanguage learners. Elementary School Journal, 100, 37-56.

Goldenberg, C. (1996). The education of language-minority students: Where are we, and where do we need to go? Elementary School Journal, 93, 353-361.

Guba, E. (1978). Toward a methodology of naturalistic inquiry in educational evaluation. CSE Monograph Series in Evaluation No. 8. Los Angeles: University of California, Los Angeles, Center for the Study of Evaluation.

Guskey, T. (1988). Teacher efficacy, self-concept, and attitudes toward the implementation of instructional innovation. Teaching and Teacher Education, 4, 63-69.

Koballa, T. \& Tippins, D. (2000). Cases in middle and secondary science education. Upper Saddle River, NJ: Merrill. 
Lather, P. (1986). Issues in validity in openly ideological research: Between a rock and a soft place. Interchange, $17,63-84$.

Lather, P. (1987). Feminist perspectives on empowering research methodologies. Paper presented at the annual meeting of the American Educational Research Association, Washington, DC.

Lather, P. (1988). Feminist perspectives on empowering research methodologies. Women's Students International Forum, 11, 569-581.

Lee, 0., Fradd, S., \& Sutman, F. (1995). Science knowledge and cognitive strategy use among culturally and linguistically diverse students. Journal of Research in Science Teaching, 32, 797816.

Macias, R. (1998). How has the limited English proficient students populations changed in recent years? National Clearinghouse for Bilingual Education. [Online]. Available: http:// www.ncbe.gqu.edu/askncbe/faqs

Mason, L. (1998). Sharing cognition to construct scientific knowledge in school context. The role of oral and written discourse. Instructional Science, 26, 359-389.

McKeon, D. (1994). When meeting common standards is uncommonly difficult. Educational Leadership, 51,45-49.

National Research Council (1996). National Science Education Standards. Washington, DC: National Academy Press.

Naumes, W. \& Naumes, M. (1999). The art and craft of case writing. Thousand Oaks, CA: Sage.

Patton, M. (1990). Qualitative evaluation and research methods. Newbury Park, CA: Sage.

Rakow, S. \& Bermudez, A. (1993). Science is "Ciencia": Meeting the needs of Hispanic American students. Science Education, 77, 669-683.

Reinharz, S. (1992). Feminist methods in social research. New York: Oxford University Press.

Roseberry, A., Warren, B., \& Conant, F. (1990). Appropriating scientific discourse: Findings from language minority classrooms. Boston: Bolt Beranek and Newman.

Schon, D. (1987). Education the reflective practitioner. San Francisco: Jossey-Bass.

Shulman, L. (1986). Those who understand: Knowledge growth in teaching. Educational Researcher, 15, 4-14.

Sleeter, C. (2001). Preparing teachers for culturally diverse schools: Research and the overwhelming presence of whiteness. Journal of Teacher Education, 52, 94-106.

Systemic Teacher Excellence Preparation (2001). STEP faculty observations. [Available online], http: www.oerl.sri.com/instruments/te/obsvclassrom/instr76.html.

Teachers of English to Speakers of Other Languages (1997). ELL standards for preK-12 students. Alexandria, VA: Author.

Tippins, D., Koballa, T., \& Payne, B. (2002). Learning from cases: Unraveling the complexities of elementary science teaching. Boston: Allyn and Bacon.

Valdes, G. (1998). The world outside and inside schools: Language and immigrant children. Educational Researcher, 27, 4-18.

Vine, E. (1997). Language across the curriculum: The language learning potential in a science context. Wellington, NZ: New Zealand Council for Educational Research.

Willis, S. (1996). Gender justice and the mathematics curriculum: Four perspectives. In L. Parker, L. Rennie, \& B. Fraser (Eds.), Gender, science and mathematics: Shortening the shadow (pp. 41-51). Boston: Kluwer. 